\section{Acknowledgment}

This work was supported by the Applied Research Training Program of Jiangxi Province (No. 20181BBG78057) and the National Natural Science Foundation of China (No. 81760539).

Keywords: Acute lymphoblastic leukemia, Multiple myeloma, Therapy-related, Genetics, Immunophenotyping

Anahtar Sözcükler: Akut lenfoblastik lösemi, Multipl myelom, Terapi ilişkili, Genetik, İmmünfenotipleme

Conflict of Interest: The authors of this paper have no conflicts of interest including specific financial interests, relationships, and/ or affiliations relevant to the subject matter or materials included.

\section{References}

1. Vardiman JW, Thiele J, Arber DA. Acute myeloid leukaemia (AML) and related precursor neoplasms. In: Swerdlow SH, Campo E, Harris NL, (eds).
WHO Classification of Tumours of Haematopoietic and Lymphoid Tissues. Lyon, IARC Press, 2008.

2. Cortes J, O'Brien $S$, Kantarjian $H_{1}$, Cork $A$, Stass $S$, Freireich EJ, Keating $M$ Pierce S, Estey E. Abnormalities in the long arm of chromosome 11 (11q) in patients with de novo and secondary acute myelogenous leukemias and myelodysplastic syndromes. Leukemia 1994;8:2174-2178.

3. Hawkins MM, Wilson LM, Stovall MA, Marsden HB, Potok MH, Kingston JE, Chessells JM. Epipodophyllotoxins, alkylating agents, and radiation and risk of secondary leukaemia after childhood cancer. BMJ 1992;304:951-958.

4. Lau LG, Tan LK, Koay ES, Liu TC. Acute lymphoblastic leukemia after tandem autologous stem cell transplantations for multiple myeloma. Leukemia 2005:19:299-301.

5. Foon KA, Thiruvengadam R, Saven A, Bernstein ZP, Gale RP. Genetic relatedness of lymphoid malignancies. Transformation of chronic lymphocytic leukemia as a model. Ann Intern Med 1993;119:63-73.

6. Makower D, Venkatraj U, Dutcher JP, Wiernik PH. Occurrence of myeloma in a chronic lymphocytic leukemia patients after response to differentiation therapy with interleukin-4. Leuk Lymphoma 1996;23:617-619.

\title{
ALK + Anaplastic Large Cell Lymphoma of Null Cell Phenotype with Leukemic Transformation and Leukemoid Reaction
}

\author{
Lösemi Transformasyonu ve Lökomoid Reaksiyon ile Giden "Null" Hücre Fenotipli ALK+ \\ Anaplastik Büyük Hücreli Lenfoma
}

\author{
(D) Shih-Sung Chuang1,2,3, (D) Yen-Chuan Hsieh1, (D) Hung-Chang Wu4 \\ ${ }^{1}$ Chi-Mei Medical Centre, Department of Pathology, Tainan, Taiwan \\ ${ }^{2}$ National Taiwan University Faculty of Medicine, College of Medicine, Department of Pathology, Taipei, Taiwan \\ ${ }^{3}$ Taipei Medical University School of Medicine, College of Medicine, Department of Pathology, Taipei, Taiwan \\ ${ }^{4}$ Chi-Mei Medical Centre, Department of Hemato-Oncology, Tainan, Taiwan
}

To the Editor,

Anaplastic large cell lymphoma (ALCL) frequently involves both nodal and extranodal sites and is rarely leukemic. A 21-yearold male presented with abdominal pain. His complete blood count, which had been normal four months ago, showed increasing white cell counts from $14.9 \times 10^{9} / \mathrm{L}$ to $95.5 \times 10^{9} / \mathrm{L}$ in a month, with neutrophils ranging from $81.6 \%$ to $89.6 \%$. Blood cultures were negative. Laparoscopic nodal biopsy showed sheets of medium-sized lymphocytes diffusely expressing CD30, TIA-1, granzyme $B$, and ALK, but not T-cell markers including $C D 2, C D 3, C D 4, C D 5, C D 7, C D 8$, and $\beta F 1$, indicating $\mathrm{ALK}+\mathrm{ALCL}$ of null cell phenotype. Bone marrow biopsy showed two small aggregates of tumor cells in a background of normal tri-lineage hematopoiesis. ALK immunostaining revealed singly scattered positive cells (Figure $1 \mathrm{~A}$ ) in addition to those in small aggregates. The staining pattern was both nuclear and cytoplasmic, indicating translocation $\mathrm{t}(2 ; 5)(\mathrm{p} 23 ; \mathrm{q} 35)$. We retrospectively reviewed the blood smear and found that $4.5 \%$ of the last peripheral smear were tumor cells, which were overlooked by the clinical laboratory. The leukemic cells were large with vesicular nuclei, irregular nuclear contours, and 


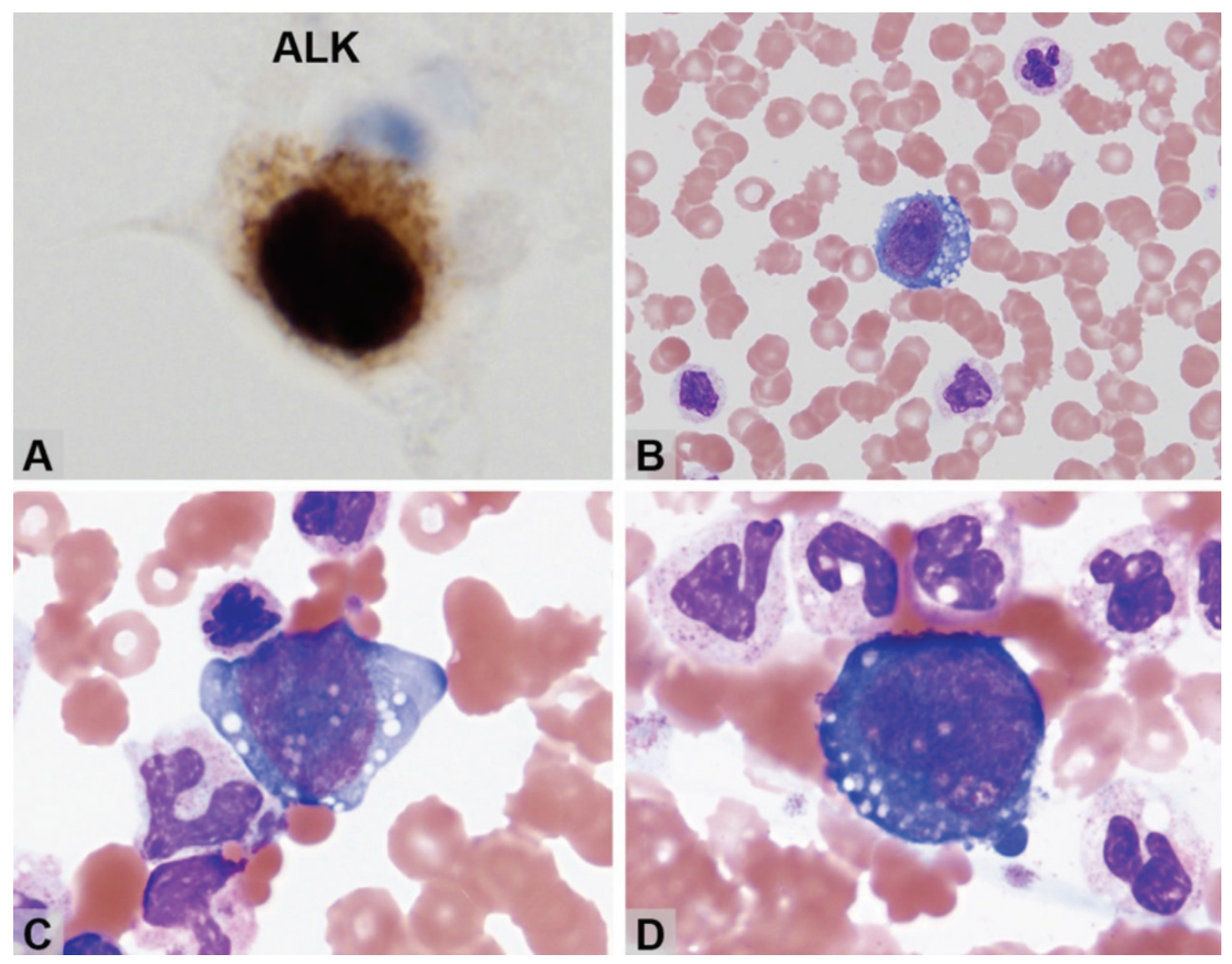

Figure 1. A) ALK immunostaining revealed singly scattered positive cells in addition to those in small aggregates; B-D) leukemic cells were large with vesicular nuclei, irregular nuclear contours, and vacuolated basophilic cytoplasm.

vacuolated basophilic cytoplasm (Figures 1B-1D). The disease progressed rapidly, and the patient passed away shortly after the first cycle of CEOP chemotherapy. In advanced diseases, ALK-positive ALCL may rarely be associated with leukemoid reaction and leukemic transformation.

Keywords: ALK, Anaplastic lymphoma kinase, Anaplastic large cell lymphoma, CD30, Leukemoid reaction, Leukemic phase, Leukemic transformation
Anahtar Sözcükler: ALK, Anaplastik lenfoma kinaz, Anaplastic büyük hücreli lenfoma, CD30, Lökomoid reaksiyon, Lösemik faz, Lösemik transformasyon

Conflict of Interest: The authors of this paper have no conflicts of interest including specific financial interests, relationships, and/or affiliations relevant to the subject matter or materials included. 